\title{
Sınıf Öğretmenlerinin Etkinlik Hazırlama ve Uygulama Süreçlerinin Değerlendirilmesi
}

\author{
Mehmet Hilmi KOÇ*
}

Öz: Bu çalışmada sınıf öğretmenlerinin etkinlik hazırlama ve uygulama süreçlerinin değerlendirilmesi amaçlanmaktadır. Araştırma eylem araştırması olarak desenlenmiş olup nicel ve nitel veri toplama tekniklerinden yararlanılmıştır. Çalışma grubunu, özel bir okulda görev yapan dokuz sınıf öğretmeni oluşturmaktadır. Örneklem türü olarak amaçlı örnekleme yöntemi seçilmiştir. Veri toplama aracı olarak görüşme, gözlem ve anket yöntemlerinden yararlanılmıştır. Görüşme ve gözlemlerden elde edilen veriler içerik analizine tabi tutulmuş; anketten elde edilen verilerin betimsel istatistikleri çıkarılmış ve eşleştirilmiş örnekler $t$ testi ile öntest ve sontest sonuçları ortaya konulmuştur. Eylem planının uygulanması sonucunda, uygulama öncesine göre, etkinlik hazırlama ve uygulama süreçlerinde olumlu yönde bir iyileşmenin olduğu tespit edilmiştir. Çalışmanın sonuçlarına göre, öğretmenlere, öğrencide düşüncenin oluşumunu sağlayacak etkinliklerin nasıl yapılacağı ile ilgili eğitimler verilmesi gerektiği söylenebilir.

Anahtar Sözcükler: Etkinlik Temelli Öğretim, Sınıf Öğretmenleri, İşbirliği, Eylem Araştırması

\section{Evaluation of Class Teachers' Activity Preparation and Implementation Processes}

\begin{abstract}
This study aimed at evaluating the activity preparation and implementation processes of classroom teachers. The study has been designed as an action research and qualitative and quantitative data collection techniques were used. The study group consists of nine classroom teachers working in a private school. As sampling type, purposeful sampling has been selected. As data collection tools, interview, observation and survey methods were used. Data obtained from the interviews and observations were subject to content analysis; the descriptive statistics of data obtained from the surveys were prepared and paired samples $t$ test and pretest as well as posttest results were displayed. As a result of the implementation of the action plan, an improvement was detected in the activity preparation and implementation processes. It is possible to say that teachers should be given trainings on how to conduct activities that would create thinking in the student.
\end{abstract}

Keywords: Activity Based Teaching, Classroom Teachers, Cooperation, Action Research 
Türkiye'de 2005 yılından itibaren uygulanmaya başlanan etkinlik temelli öğrenme fikri yapılandırmacı yaklaşım teorisine ve öğrenci merkezli pedagojiye dayanmaktadır. Yapılandırmacı yaklaşımın kurucularından Dewey öğrencilerin pratik deneyimler yoluyla öğrenmesinin faydaları üzerinde yoğun bir şekilde durmuştur. Bonwell ve Eison (1991) etkinlik temelli öğrenmeyi, öğrencilerin anlamlı öğrenme faaliyetleri yürütmeleri ve ne yaptıkları hakkında düşünmeleri olarak ifade etmektedir. Etkinlik temelli öğretim, öğrencilere kendi sorunları karşısında özgün düşünmeyi öğreten, pratik çözümler bulmasını kolaylaştıran ve öğrenme için gerekli özgüveni sağlayan bir yöntemdir (Lakshmi ve Hee, 2005). Etkinlik temelli öğretim yaklaşımının başarılı olabilmesi için öğrencilerin küçük yaşlardan itibaren bu yöntemin uygulandığı sınıflarda ders görmeleri gerekmektedir.

Türkiye'de on iki yıldan fazla bir süredir uygulanmakta olan etkinlik temelli öğretim yöntemine sınıf öğretmenlerinin ne derece uyum sağladıkları, etkinlik uygulamaları sırasında dikkat edilmesi gereken özelliklerin ne kadarını yerine getirebildikleri ve hangi yönlerden gelişim ihtiyaçlarının olduğunun bilinmesi önem arz etmektedir. Küçük yaştaki öğrencilerle ders işleyen sınıf öğretmenlerinin ders işlerken kullandıkları yöntemler daha üst sınıflarda uygulanacak etkinlik temelli çalışmalara olumlu veya olumsuz etkileri olabileceği ifade edilebilir. Üst sınıflarda etkinlik temelli işlenen derslerin başarılı olması sınıf öğretmenlerinin öğrencilerine bu yönteme göre derse katılma alışkanlığı kazandırmasına bağlıdır. Ayrıca etkinlik konusunda öğretmenlerin mevcut durumunu tespit eden çalışmaların yanında gelişime açık yönlerinin nasıl iyileştirilebileceğini gösteren çalışmalara da ihtiyaç olduğu görülmektedir.

Şahan (2000) etkinliği, dersin hedef kazanımlarına ulaşılması amacıyla öğrenme-öğretme sürecini zenginleştiren ve öğrenmede kalıcılığı artıran faaliyetler olarak tanımlamıştır. MacDonald (2008) göre etkinlik, öğrencilerin öğrenmelerini desteklemek suretiyle öğrenme düzeylerini arttıran faaliyetlerdir. Etkinlikler tek başına anlamı olmayan ancak öğretmen rehberliğinde öğrencilerle birlikte yapıldığında anlam kazanan sınıf içi faaliyetlerdir (Watson, 2008). Özmantar ve Bingölbali (2009) ise etkinliği, öğrenmeye yönelik görevlerin belirli bir pedagojik yaklaşımla hayata geçirilmesi olarak tanımlamışlardır. Doyle (1983) etkinlikleri, hatırlatma etkinlikleri, işlemsel etkinlikler, kavrama/anlamlandırma etkinlikleri ve düşündürme etkinlikleri şeklinde dörde ayırırken; Sullivan, Clarke ve Clarke (2013), temsili duruma dayalı etkinlikler, gerçek yaşam durumlarına dayalı etkinlikler ve açık uçlu etkinlikler şeklinde üç gruba ayırmışlardır. Bu açıklamalardan yola çıkarak araştırmacıların etkinlik kavramına farklı anlamlar yükledikleri ileri sürülebilir.

Öztürk (2016), etkinliklerde bulunması gereken niteliklere ilişkin bazı araştırmacılar tarafından ortaya konulan özellikleri maddeler halinde sıralamıştır. Buna göre etkinliklerin; amaca uygun olma, üst düzey düşünmeyi gerektirme, gerçek yaşam durumların içerme, öğrencilerin ön bilgilerini dikkate alma, materyal içerikli olma, öğrenci seviyesine uygun olma, öğrencilerin model oluşturmalarına fırsat verme, merak uyandıracak nitelikte olma, motivasyonu arttırma, öğrencilerin bireysel farklılıklarını dikkate alma, birden fazla duyu organına hitap etme, kullanılan öğretim yöntemine uygun olma, akıl yürütme becerisini gerektirme, aktif katılımı sağlama, sınıf yönetimini zorlaştırmayacak şekilde olma, öğrencilerin tartışmalarına fırsat verme, öğrencilerin etkileşimlerini sağlama, uygulanabilir olma, bireysel öğrenme stillerine uygun olma, öğrenci merkezli olma, birden fazla başlangıç noktasına sahip olma, kalıcı ve etkili öğrenmeye fırsat sağlama, sınıfın fiziki yapısına uygun olma, süreç içerisinde ölçme ve değerlendirmeye imkân tanıma ve belirli bir süre planının olması gibi özellikler taşıması gerekmektedir.

Öğretmenler etkinlik uygulama sürecinde yaşadıkları problemlerden kurtulmak için uygulama sürecini gözden geçirmek yerine, kullandıkları etkinliklerden vazgeçme yoluna gidebilmektedirler (Bal, 2008; Horoks ve Robert, 2007; Özmantar, Bozkurt, Demir, Bingölbali ve Açll, 2010). Horoks ve Robert (2007) bunu, öğretmenlerin etkinlik kullanımıyla ilgili yeterli bilgiye sahip olmamalarına bağlamaktadırlar. Ayrıca öğretmenlerin önceden planlama yapmadan uygulamaya koydukları etkinlikler öğretimi ve öğrenmeyi desteklemek ve kolaylaştırmaktan ziyade engel oluşturduğu, zaman ve emek kaybına yol açtı̆̆1 belirtilmektedir (Bell, 1993; Swan, 2007). Watson (2008) etkinliğin öğrenmenin gerçekleşmesinde bir araç olduğunu ve bu aracın anlamlı hale gelmesinde etkinliğin uygulayıcısı olan öğretmenin yetkin olması gerektiğini söylemektedir. Etkinlik temelli öğrenmeyi gerçekleştirecek öğretmenin, açık fikirli, kendini 
Sınıf Öğretmenlerinin Etkinlik Hazırlama...

yenileyebilen, bireysel farklılıkları dikkate alan, uygun öğrenme yaşantılarını sağlayan ve öğrenenlerle birlikte öğrenen biri olması gerekmektedir (Selley, 1999). Etkinlik temelli öğrenmenin etkililiğini ve verimini artırmak, öğretmen eğitimini düzeltmek ve geliştirmekten geçmektedir (Hallinan ve Khmelkov, 2001). Etkinliklerin etkili bir şekilde hazırlanıp uygulanabilmesi için öğretmenlerin gerekli bilgi ve donanıma sahip olmaları gerekmektedir.

Aykaç (2007), yapmış olduğu araştırmasında; sınıf öğretmenlerinin etkinlikleri uygulamada kendilerini yetersiz gördüklerini, okulların fiziki imkânlarının ve okullarda bulunan araç-gereçlerin etkinlikleri uygulamak için yetersiz olduğunu ve sınıfların kalabalık olması nedeniyle öğretmenlerin etkinlikleri uygulamakta zorlandıklarını ifade etmektedir. Özmantar, Bozkurt, Demir, Bingölbali ve Açıl'a (2010) göre, sınıf öğretmenlerinin etkinlik kavramına dair algıları; öğrencilerin ders sürecine aktif olarak katılımlarını gerektiren, öğrenmenin kalıcı olmasını sağlayan ve öğrenilen bilgilerin pekiştirilmesi amacıyla kullanılan sınıf içi çalışmalar şeklinde çeşitlilik göstermektedir. Açıl (2011), bazı öğretmenler etkinliği öğrencilerin aktif katılımına dayalı çalışmalar olarak, bazı öğretmenler öğrenci sürece aktif olarak katılsın ya da katılmasın sınıfta yapılan her türlü çalışma olarak ve bazı öğretmenlerin de öğrenilen bir konuyu pekiştirmek için tahtaya soru yazıp bunu öğrencilerin çözmesini bir etkinlik olarak algıladıklarını tespit etmiştir. Öcal (2012) bir ilköğretim okulundaki sınıf ve branş öğretmenleri ile yürüttüğü çalışmasında; öğretmenlerin etkinlikleri uygularken öğrencilere rehberlik etme ve yol gösterme rollerini yerine getirmeye çalıştıklarını, ancak sınıf mevcudunun çok olması, materyal eksikliği ve sürenin yetmemesi konuların da sorun yaşadıklarını ve etkinlikleri değerlendirmek için ölçme-değerlendirme tekniklerini yeterince kullanmadıklarını tespit etmiştir. Süleymangil (2013) sınıf içi öğretim etkinliği geliştirme ve uygulama çalışmalarının, sınıf öğretmenlerinin mesleki becerilerini geliştireceği sonucuna ulaşmıştır. Akhalq, Chishti ve Iqbal (2016), Pakistan'da ilkokul öğretmenlerine, öğrencilerin zihinsel yeteneklerine uygun materyaller geliştirmek suretiyle onları etkinlik temelli öğretime dahil edebilmelerini sağlayacak hizmet-içi eğitimler verilmesi gerektiğini belirtmektedirler.

Bu çalışmada, sınıf öğretmenlerinin etkinlik hazırlama ve uygulama süreçlerinin değerlendirilmesine yönelik bir eylem araştırması yapılması amaçlanmıştır. Bu doğrultuda özel bir ilkokulda görev yapan sınıf öğretmenlerinin, etkinlik konusunda sahip oldukları algıları, etkinlik hazırlama ve uygulama süreçlerinde geliştirilmesi gereken yönleri ve çözüm önerileri ortaya konulmaya çalışılmıştır. Söz konusu özel okulun 1, 2 ve 3. sınıf zümre başkanları sınıf öğretmenlerinin etkinlik geliştirme ve uygulama süreçlerinin iyileştirilebilmesi için araştırmacıdan destek istemişlerdir. Araştırmacı zümre başkanları ile ön görüşme yaparak 1, 2 ve 3. sınıflardaki etkinlik çalışmaları hakkında bilgi almıştır. Zümre başkanları; zümre olarak hep birlikte ortak ve özgün etkinlikler hazırlamak istediklerini, ancak öğretmenler arasında etkinlik kavramına bakış açılarında farklılıklar olduğunu, bazı öğretmenlerin çok yüzeysel etkinlik çalışmaları yaptıklarını, özgün etkinlik hazırlamak yerine kitaplardaki ders sonu pekiştirme etkinliklerini kullanıldığını, yapılan etkinliklerin genelde bilişsel düzeyin bilgi ve kavrama basamağına hitap ettiğini ve öğrencilerin derse aktif katılımının yeterince sağlanamadığını ifade etmişlerdir. Bu bilgilerin ışığında sınıf öğretmenlerinin ders içi etkinlik geliştirme ve uygulama süreçlerinin iyileştirilebilmesi için eylem araştırması yönteminin kullanılması araştırmacı tarafından zümre başkanlarına önerilmiş ve onların da uygun görmesi ile eylem araştırmasının yapılmasına karar verilmiştir.

\section{Yöntem}

Bu araştırmanı amacı, özel bir ilkokulda çalışan dokuz sınıf öğretmeninin etkinlik hazırlama ve uygulama süreçlerini incelemektir. Bu amaç doğrultusunda araştırma eylem araştırması olarak desenlenmiş, nicel ve nitel veri toplama tekniklerinden yararlanılmıştır. Eylem araştırması, öğretmenin daha kaliteli bir eğitimöğretim süreci yürütmesine yönelik mesleki bir bakış açısı geliştirmesini (Schmuck, 1997) veya kendi uygulamaları hakkında sistematik yansımalar yapmasını sağlamak olarak ifade edilebilir (Johnson, 2012). Eğitim ortamlarındaki eylem araştırmaları, araştırmacı ve katılımcıların süreç üzerindeki kontrollerinin farklılığına bağlı olarak çeşitli şekillerde sınıflandırılmaktadır. Bu araştırmada kullanılan eylem araştırmasının türünün, uygulama odaklı (karşılıklı işbirliği/uygulama/tartı̧ma) eylem araştırması olduğu söylenebilir (Ferrance, 2000; Norton, 2009; Yıldırım ve Şimşek, 2016). Araştırmada eylem araştırması modellerinden biri 
olan Mills Modeli kullanılmıştır. Mills (2011) eylem araştırmasını, öğretmenlerin eğitim-öğretim faaliyetlerini nasıl yürüttükleri hakkında bilgilerin toplandığı ve devamında ise gelişmeye yönelik eylemlerin gerçekleştirildiği sistematik bir süreç olarak ifade etmiştir. Mills Eylem Araştırması Döngüsü içinde yer alan adımlar, odaklanılacak alanı belirleme, veri toplama, verileri analiz etme ve yorumlama ve eylem planı geliştirme aşamalarından oluşmaktadır (Mills, 2011). Mills eylem araştırması döngüsünden yola çıkılarak araştırmacı kendi eylem araştırması döngüsünü oluşturmuştur. Araştırmacı tarafından yapılan eylem araştırmasının döngüsünün aşamaları şunlardır: Sınıf öğretmenlerinin etkinlik hazırlama ve uygulama süreçlerinin incelenmesi; katılımcılara anket uygulanması ve görüşme yapılması; anket ve görüşmelerden elde edilen verilerin analizi ve yorumlanması; etkinliklerin hazırlanması, uygulanması ve değerlendirilmesi aşamalarında nelere dikkat edileceği ile ilgili katılımcılara eğitim verilmesi; her zümredeki öğretmenlerin kendi aralarında işbirliğine giderek en az iki etkinlik hazırlamaları; etkinlik çalışmalarının sınıf ortamında gözlenmesi ve anketin tekrar uygulanması; yapılan gözlemlerden ve uygulanan ilk ve son anketlerden elde edilen verilerin analizi ve yorumlanması.

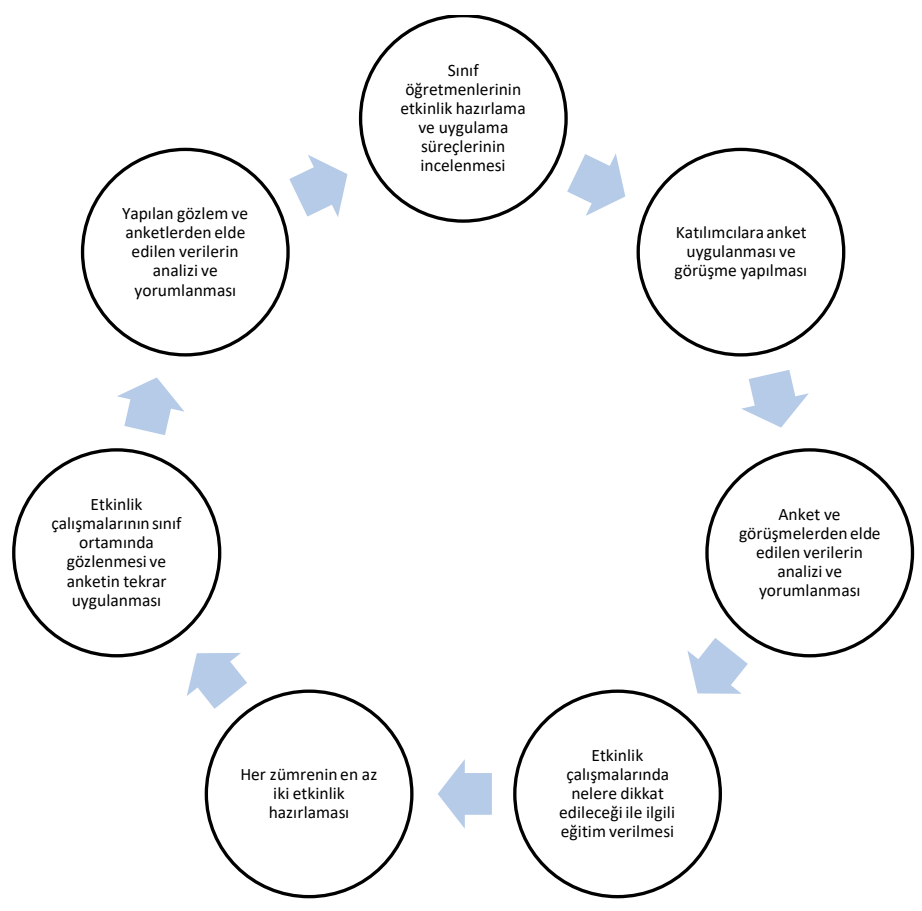

Şekil 1. Etkinlik hazırlama ve uygulama süreçlerinin incelenmesine ilişkin yapılan eylem araştırmasının diyalektik döngüsü.

Mills (2011) eylem araştırması sürecinde ilk olarak odaklanılacak konunun belirlenmesinin önemli olduğunu belirtmektedir. Bu çalışmada odağında sınıf öğretmenlerinin etkinlik hazırlama ve uygulama süreçleri yer almaktadır. Söz konusu okuldaki 1., 2. ve 3. sınıf zümre başkanlarının yapmış oldukları ders içi etkinlik çalışmalarının değerlendirilmesi ve geliştirilmesi için destek istemeleri üzerine araştırmacı kurum dışından katılımcı (öğretim üyesi) olarak sürece dahil olmuştur. Sınıf öğretmenlerinin etkinlik hazırlama ve uygulama süreçlerine ilişkin veriler çeşitli yöntemlerle toplanıp analiz edilmiş, yorumlanmış ve iyileştirme çalışılmaları yapılmıştır.

\section{Çalışma Grubu}

Çalışma grubunu, 2017-2018 eğitim yılında İstanbul ilinin Çekmeköy ilçesindeki bir özel okulda görev yapan 9 ilkokul öğretmeni oluşturmaktadır. Çalışma grubu, söz konusu özel ilkokulda görev yapan 1. 2. ve 3. sınıf öğretmenlerinden oluşmaktadır. Araştırmada seçkisiz olmayan örnekleme yöntemlerinden amaçlı örnekleme yöntemi kullanılmıştır. Amaçlı örnekleme yöntemi bilgi yönünden zengin olduğu düşünülen durumların derinlemesine çalışılmasına imkân vermektedir (Yıldırım ve Şimşek, 2016). Strateji olarak maksimum çeşitlilik stratejisi seçilmiştir. Maksimum çeşitlilik örnekleme stratejisinde evrende incelenen 
problemle ilgili olarak kendi içinde benzeşik farklı durumların belirlenerek çalışmanın bu durumlar üzerinde yapılması sağlanır (Büyüköztürk, Çakmak, Akgün, Karadeniz ve Demirel, 2008). Burada amaç, çeşitliliği sağlamak yoluyla evrende genelleme yapmak değil, çeşitlilik gösteren durumlar arasındaki benzerliklerin ve farklılıkların neler olduğunu ortaya çıkarmaktır (Yıldırım ve Şimşek, 2016). Bu bağlamda çalışmanın yapılacağ Katılımcılara ilişkin demografik bilgiler Tablo I'de sunulmuştur:

Tablo I

Katılımciların Demografik Özellikleri

\begin{tabular}{|c|c|c|c|c|}
\hline Sira No & Rumuz & Cinsiyet & Mesleki Kıdem & Okuttuğu Sınıf \\
\hline 1 & $\mathrm{~K}_{\mathrm{I}-1}$ & Kadın & 17 & 1. sinif \\
\hline 2 & $\mathrm{~K}_{\mathrm{I}-2}$ & Erkek & 19 & 1. sinif \\
\hline 3 & $\mathrm{~K}_{\mathrm{I}-3}$ & Erkek & 3 & 1. sinif \\
\hline 4 & $\mathrm{~K}_{\mathrm{II}-4}$ & Erkek & 9 & 2. sinif \\
\hline 5 & $\mathrm{~K}_{\text {II- }-5}$ & Kadın & 6 & 2. sinif \\
\hline 6 & $\mathrm{~K}_{\text {II- }-6}$ & Erkek & 13 & 2. sinif \\
\hline 7 & KIII-7 & Kadın & 4 & 3. sinif \\
\hline 8 & KIII-8 & Kadın & 7 & 3. sinif \\
\hline 9 & KIII-9 & Kadın & 11 & 3. sinif \\
\hline
\end{tabular}

Araştırmaya katılan öğretmenlerin 2'si 1-5 yıl, 3'ü 6-10 yıl, 2'si 11-15 yıl, 2'si 16 yıl ve üstü mesleki kıdeme sahip oldukların ifade etmişlerdir. Araştırmaya katılan öğretmenlerin 4'ü erkek 5'i kadındır. Araştırmada her katılımcıya bir rumuz verilmiştir. Örneğin; "KI-1: Birinci sınıfı okutan birinci katılımcı", "KII-4: İkinci sınıfı okutan dördüncü katılımcı", "KIII-8: Üçüncü sınıfı okutan sekizinci katılımcı".

\section{Veri Toplama Aracı}

Nicel verilerin toplanmasında Koç (2018) tarafından geliştirilen "Etkinlik Çalışmaları Değerlendirme Ölçeği" (EÇDÖ) kullanılmıştır. EÇDÖ tek faktörden ve 12 maddeden oluşmaktadır. EÇDÖ'nün madde toplam korelasyon değerleri 0,59 ile 0,84 arasında değişmektedir. Ölçeğin tamamı için hesaplanan Cronbach's Alpha katsayısı 0,96 olarak bulunmuştur. Elde edilen bulgulara göre, EÇDÖ'nün iç tutarlılığının, geçerlik ve güvenirliliğinin oldukça yeterli düzeyde olduğu ifade edilebilir. EÇDÖ ile katılımcıların etkinlik konusundaki algıları, yetkinlik düzeyleri ve geliştirilmesi gereken yönleri tespit edilmeye çalışılmıştır.

Öğretmenler tarafından yapılan etkinliklere ilişkin önceki çalışmalarının incelenmesi ve öğretmenlerle görüşmeler yapılması suretiyle yarı-yapılandırılmış görüşme formu oluşturulmuştur. Uzman görüşleri alınmak suretiyle görüşme formuna son hali verilmiştir. Yarı-yapılandırılmış görüşme formu kullanılarak katılımcıların tamamıyla yüz-yüze görüşmeler yapılmıştır. Her bir görüşme ortalama 35-40 dakika sürmüş ve kayıt cihazına kaydedilmiştir. Görüşme formunda dört tane soru bulunmaktadır. Sorulara ek olarak katılımcılar için sorulara farklı anlamlar yüklenmesi ihtimaline karşı 1. Etkinliklere dayalı bir öğretim sürecinin öğretmenlere ne gibi faydalar să̆layacağını düşünüyorsunuz? 2. Bir konunun öğrenilmesinde yaptı̆̆ınız etkinlik sayısını yeterli buluyor musunuz? 3. Etkinlikler öğrencilerin potansiyellerinin ortaya çıkaracak ve geliştirecek şekilde mi? gibi alternatif sorular hazırlanmıştır.

Araştırmacı planın uygulama aşamasında yapılandırılmış gözlem yaparak veri toplama yoluna gitmiştir. Gözlem herhangi bir ortamda davranışı ayrıntılı olarak tanımlamamızı sağlar (Yıldırım ve Şimşek, 2016). Yapılandırılmış gözlem formu hazırlanırken öncelikle taslak form oluşturulmuştur. Taslak formun oluşturulmasında, uygulama önsesi yapılan görüşmelerden, anketten ve literatürde yapılan çalışmalardan yararlanmıştır. Hazırlanan bu taslak form uzman görüşlerine sunulmuştur. Uzman görüşleri doğrultusunda forma son şekli verilmiştir. On beş maddeden oluşan gözlem formu ile katılımcıların, etkinlikleri hazırlarken kazanımları ve öğrenci düzeyini dikkate alma, zamanı planlama, öğrencilerin aktif katılımı sağlama, materyal kullanma, öğrencilerin düşünme becerilerini geliştirmeye çalışma ve etkinlik esnasında öğrenci davranışlarını kontrol etme gibi durumları gözlenmeye çalışılmıştır. Yapılandırılmış gözlem formu eylem planının uygulama aşamasında kullanılmış ve her bir katılımcının farklı derslerde yaptı̆̆ en az iki etkinlik gözlenmiştir. İki etkinlikte gözlenen davranışların ortalaması alınmıştır. Hangi derste hangi etkinlik ile ilgili 
gözlem yapılacağı her bir katılımcı ile ön görüşme yapılarak belirlenmiştir. Katılımcıların gözlenmesini istedikleri ve iyi hazırlık yaptıklarını düşündükleri etkinliklerin gözlenmesine dikkat edilmiştir. Gözlemlerin tamamı araştırmacı tarafından sınıf ortamında yapılmıştır. Gözlem esnasında araştırmacı, sınıfın en arkasında kendisine ayrılan yere oturmuş ve yaptığı gözlemleri not almıştır. Araştırmacı bazen bazı etkinlikleri gözlemlerken ders süresinin tamamında sınıfta bulunmuş bazen de sadece etkinliğin yapıldığı süre kadar sınıfta bulunmaya çalışmıştır. Gözlemler sonrasında nelerin iyi yapıldığı ve hangi yönlerin geliştirilmesi gerektiği ile ilgili değerlendirme yapmak için her bir katılımcı ile bire bir görüşmeler yapılmıştır. $\mathrm{Bu}$ görüşmelerde araştırmacı yapıcı bir dil kullanarak önerilerini dile getirmiş ve katılımcının da duygu ve düşüncelerini alarak çalışmayı tamamlamıştır.

\section{Uygulama Süreci}

Bu bölümde eylem araştırması kapsamında yürütülen çalışmaların detaylarından söz edilmektedir. Aşağıda Tablo II'de uygulama sürecinin detayları verilmiştir.

Tablo II

Eylem Planının Aşamaları ve Araştırma Verilerini Toplama Zamanları

\begin{tabular}{ll}
\hline Etkinlikler & Tarih \\
\hline Zümre başkanları ile ön görüşme yapılması & $01 / 10 / 2017$ \\
\hline Uygulama Öncesi Yapılan Çalışmalar & $07 / 11 / 2017$ \\
\hline Anket formunun uygulanması & $08 / 11 / 2017$ \\
3 öğretmenle görüşme yapılması & $10 / 11 / 2017$ \\
2 öğretmenle görüşme yapılması & $14 / 11 / 2017$ \\
3 öğretmenle görüşme yapılması & $16 / 11 / 2017$ \\
1 öğretmenle görüşme yapılması & $21 / 11 / 2017$ \\
\hline Öğretmenlere verilerin analizinin sunulması & $28 / 10 / 2017-18 / 11 / 2017$ \\
\hline Uygulama Planı Geliştirmesi Aşamasında Yapılanlar & $21-30 / 11 / 2017$ \\
\hline Etkinliklerin hazırlanması, uygulanması ve değerlendirilmesi aşamalarında nelere dikkat edileceği ile & $01-08 / 12 / 2017$ \\
ilgili eğitim verilmesi & $10-19 / 12 / 2017$ \\
Her zümrenin kendi aralarında işbirliğine giderek en az iki etkinlik hazırlaması & \\
\hline Uygulama Sürecinde Yapılan Çalışmalar & $20-28 / 12 / 2017$ \\
\hline 1. Sınıf öğretmenlerinin etkinlik çalışmalarının gözlenmesi ve gözlem sonrası öğretmenlerle görüşmeler & \\
yapılması & \\
2. Sınıf öğretmenlerinin etkinlik çalışmalarının gözlenmesi ve gözlem sonrası öğretmenlerle görüşmeler & $203 / 01 / 2018$ \\
yapılması & $10 / 01 / 2018$ \\
\hline 3. Sınıf öğretmenlerinin etkinlik çalışmalarının gözlenmesi ve gözlem sonrası öğretmenlerle görüşmeler & 2 \\
yapılması & \\
Anket formunun tekrar uygulanması & \\
Kapanış Toplantısı & \\
\hline
\end{tabular}

\section{Verilerin Analizi}

Eylem araştırması uygulama öncesi, uygulama planının geliştirilmesi ve uygulama aşamalarından oluşmaktadır. Uygulama öncesinde katılımcılara anket uygulanmış ve birebir görüşme yapılmıştır. Uygulama aşamasında ise katılımcıların etkinlik uygulamaları gözlenmiş, gözlem sonrası her katılımcı ile birebir görüşme yapılmış ve ilk başta uygulanan anket katılımcılara tekrar uygulanmıştır.

Araştırmada görüşme yoluyla toplanan veriler analiz aşamasında veri analizi çeşitlerinden "içerik analizi" tekniğine tabi tutulmuştur. İçerik analizi ile toplanan verileri açılayabilecek kavramlara ve ilişkilere ulaşmak amaçlanmıştır. Birçok kez incelenerek belirlenen kod ve temalarla bulgular elde edilmiş ve elde edilen bu bulgular, araştırma grubuna ait görüşmelerden alıntılarla desteklenerek yorumlanmıştır. Gözlem formlarının doldurulmasıyla elde edilen veriler içerik analizine tabi tutulmuştur. Bu bağlamda gözlem formunda yer alan gözlenen durumlar tablolar halinde ortaya konularak açıklanmıştır. Gözlem formunda yer alan davranışlardan hangilerinin gözlemlendiği, hangilerinin ise gözlemlenemediği ortaya konularak yorumlanmıştır. Nitel araştırmalarda inandırıcılık ölçütlerinden biri olan katılımcı onayını almak için katılımcılardan görüşme kayıtlarını kontrol etmeleri istenmiştir. Bu sayede katılımcıların deneyim ve yorumlamaları arasında uyum olup olmadığı incelenmiştir (Guba, 1981). Ayrıca oluşturulan kod ve temalar 
üç uzmanın incelemesine sunulmuştur.

Araştırmanın nicel analiz sürecinde ise SPSS 21.0 istatistiksel paket programı kullanılmıştır. Verilerin değerlendirilmesinde aritmetik ortalama ve standart sapmalar hesaplanmış, ayrıca öntest ve sontest sonuçları eşleştirilmiş örnekler $\mathrm{t}$-testi ile test edilmiştir. Katılımcıların sorulara verdikleri yanıtların aritmetik ortalamaları değerlendirilirken şu değerlendirme aralıkları esas alınmıştır: "1.00-1.79 = Kesinlikle Katılmıyorum”, “1.80-2.59 = Katılmıyorum”, “2.60-3.39 = Kararsızım”, “3.40-4.19= Katıliyorum ”, “4.20-5.00 $=$ Kesinlikle Kat1liyorum ".

\section{Geçerlik ve Güvenirlik}

Eylem araştırmalarının gücü verilerin tek bir kaynaktan değil, birçok yoldan toplanması anlamına gelen çeşitlemede yatmaktadır. Çeşitleme birden fazla veri kaynağının, elde edilen bilgileri doğrulamak için kombine edilmesidir (Daymon ve Holloway, 2005). Bu araştırmada hem yöntem hem de veri kaynaklarının çeşitlendirilmesine gidilmiştir. Ayrıca anket, gözlem ve görüşme gibi farklı veri kaynakları kullanılarak derinlemesine ve zengin veriler elde edilmiştir.

Veri kaynakları ile uzun süreli etkileşimde bulunulması araştırmanın inandırıcılığını yükselten önemli stratejilerden biridir. On beş hafta süren araştırma uygulama öncesi, uygulama planının geliştirilmesi ve uygulama aşamalarından oluşmaktadır. Uygulama öncesinde, öğretmenlere anket düzenlenmiş ve görüşmeler yapılmış; uygulama esnasında katılımcılara etkinliklerin hazırlanması, uygulanması ve değerlendirilmesine ilişkin eğitimler verilmiş; uygulama sürecinde ise gözlem, görüşme ve son test yapılmıştır. Uygulama sürecinde araştırmacı, çalışma grubu ile düzenli olarak etkileşimde bulunmuş, bireysel ve grup halinde görüşmeler yaparak onlarla bir araya gelmiştir. Bu şekilde katılımcıların bakış açılarını daha doğru bir şekilde anlamaya çalışmış ve onların araştırmacıya olan güven duygularının artmasını sağlamıştır. Toplanan verilerin kodlanması, temalanması ve analizinde eleştirel bakış getiren üç uzman geri bildirimde bulunmuştur. Uzmanlardan ikisi akademisyen ve biri öğretmendir. Uzmanların ve araştırmacının sahip oldukları farklı yorum ve görüşler üzerinde tartışmalar yapılarak rafine bir analiz yapılması sağlanmaya çalışılmıştır.

\section{Bulgular}

Bu bölümde eylem planının, uygulama öncesi, uygulama planının geliştirilmesi ve uygulamanın yapılması sürecinde toplanan verilerden elde edilen bulgular yer almaktadır.

\section{Uygulama Öncesi Elde Edilen Bulgular}

Katılımcılara "etkinlik çalışmaları değerlendirme ölçeği" uygulanmıştır. Katılımcıların "EÇDÖ"ye verdikleri cevapların değerlendirilmesi sonucunda elde edilen aritmetik ortalamalara ilişkin betimsel istatistikler Tablo III'de verilmiştir.

\section{Tablo III}

Etkinlikleri Çalışmaları Değerlendirme Ölçeğinin Uygulanması Sonucunda Elde Edilen Aritmetik Ortalama, Standart Sapma ve Göreli Önem Sıra Değerleri

\begin{tabular}{|c|c|c|c|c|}
\hline Sira No & Iffadeler & $\bar{X}$ & ss & Önem Sirası \\
\hline & Derslerde yaptığım etkinlikler; & & & \\
\hline 1 & Öğrencilerin bireysel yeteneklerinin ortaya çıkmasına katkı sağlar & 3,37 & 43 & 11 \\
\hline 2 & Öğrencilerin sosyalleşmesine yardımcı olur & 4,54 &, 51 & 3 \\
\hline 3 & Öğrencilere üst düzey düşünme becerileri kazandırır & 3,46 &, 51 & 10 \\
\hline 4 & Öğrencilere bağımsız çalışma alışkanlığı kazandırır & 3,83 &, 59 & 8 \\
\hline 5 & Öğrencilerin başarma duygusunu tatmalarını sağlar & 4,46 & 66 & 4 \\
\hline 6 & İçerik günlük yaşamdan kopuk değildir & 4,38 & ,76 & 5 \\
\hline 7 & Öğrencileri araştırma yapmaya yöneltir & 3,29 & 48 & 12 \\
\hline 8 & Öğrencilerin özgüven duygularını geliştirir & 3,92 & 64 & 7 \\
\hline 9 & Öğrencilerin arkadaşlarıyla kaynaşmasına yardımcı olur & 4,62 &, 51 & 2 \\
\hline 10 & Öğrencilerin duygusal gelişimine katkı sunar & 4,18 & 65 & 6 \\
\hline
\end{tabular}




\begin{tabular}{lllll}
\hline 11 & Bilgi yükü yerine, bilgi kazanma süreçlerine göre hazırlanmıştır & 3,75 &, 68 & 9 \\
12 & Öğrencilerin olumlu davranış kazanmasına olanak sağlar & 4,69 &, 48 & 1 \\
\hline
\end{tabular}

Tablo III incelendiğinde katılımcıların yaptıkları etkinliklerin en güçlü beş yönünün; öğrencilerin olumlu davranış kazanması, arkadaşları ile kaynaşması, sosyalleşmesi, başarma duygusunu tatması ve içeriğin günlük yaşamdan kopuk olmaması şeklinde olduğu görülmektedir. Öğretmenlerin yaptıkları etkinliklerin en zayıf beş yönü ise; öğrencileri araştırma yapmaya yöneltme, bireysel yeteneklerinin ortaya çıkmasına katkı sunma, üst düzey düşünme becerisi kazandırma, temel beceriler ile düşünme becerilerini bütünleştirme, bilgi yükü yerine bilgi kazanma süreçlerine göre etkinlik hazırlama ve bağımsız çalışma alışkanlığı kazanma şeklinde olduğu anlaşılmaktadır.

Etkinliklere dayalı öğretimin öğretmene faydaları temasının kodları ve frekansları Tablo IV'de sunulmaktadır.

Tablo IV

Etkinliklere Dayalı Öğretimin Öğretmene Faydaları Temasına İlişkin Alt Temalar ve Frekanslar

\begin{tabular}{lll}
\hline Ana tema & Alt temalar & f \\
\hline & Öğrenciyi merkeze alma & 9 \\
& Dikkati sağlama & 7 \\
& Kalı̈ı ögrenme & 6 \\
Etkinliklere Dayalı Öğretimin & Dersten haz alma & 5 \\
Öğretmene Faydaları & Değerlendirme yapabilme & 4 \\
& Gözlem yapabilme & 3 \\
& Konuları somutlaştırma & 2 \\
& Zamanın daha akıcı geçmesi & 1 \\
\hline
\end{tabular}

Tablo IV incelendiğinde etkinliklere dayalı öğretimin öğretmene faydaları temasının, “öğrenciyi merkeze alma", "dikkati sağlama", "kalıcı öğrenme", "dersten haz alma", "değerlendirme yapabilme", "gözlem yapabilme", "konuları somutlaştırma" ve "zamanın daha akıcı geçmesi" şeklinde sekiz alt temada toplandığı görülmektedir. Tablo IV'te ki alt temalar ve frekans sayıları dikkate alındığında öğretmenlerin etkinlik temelli öğretimin önemini yeterince kavrayamadıkları ve etkinliklerden yeterince faydalanamadıkları ileri sürülebilir. Etkinliklere dayalı öğretimin öğretmene faydaları temasına ilişkin katılımcı görüşlerinin bir bölümü aşağıda yer almaktadır.

\footnotetext{
“Öğrenciyi merkeze almış oluyoruz. Böylece öğrenci derste daha aktif oluyor. Soyut olan konuların somutlaşmasını sağlıyoruz. Etkinlikler günlük hayata yakın olmalı afaki olmamalı. Çünkü etkinliğe katılmayan öğrenci çok üzülüyor. Öğrenciyi merkeze aldığınızda dersten daha çok verim alıyorsunuz. Etkinliklerin mümkün olduğunca sınıfa ve kazanımlara uygun olmasına dikkat etmemiz gerekiyor. Keşke her öğrencinin özelliklerine göre etkinlikler yapabilsek." KIII-7

"Bizim için daha eğlenceli oluyor. Daha rahat işlediğimiz bir ders oluyor. Vicdanen daha rahat ediyoruz. Tüm öğrencilerin derse ilgisinin olması bizi daha mutlu ediyor. En ufağından bir hikâye geçen sene öğrendikleri bir şarkı hala akıllarında ve kalıcı öğrenme gerçekleşmiş oluyor." KII-6
}

Öğretmen "KIII-7", etkinlikler sayesinde öğrenci merkezli ders işleyip konuları somutlaştırabildiğini, öğretmen "KII-6" derslerin eğlenceli hale geldiğini ve kalıcı öğrenmenin gerçekleştiğini ifade etmektedirler.

Görüşmeler sonucunda oluşturulan diğer bir tema "etkinliklere dayalı bir öğretimin öğrenciye faydaları" temasıdır. Etkinliklere dayalı öğretimin öğrenciye faydaları temasının kodları ve frekansları Tablo V'te sunulmaktadır.

Tablo V.

Etkinliklere Dayalı Öğretimin Öğrenciye Faydaları Temasına İlişsin Alt Temalar ve Frekanslar

\begin{tabular}{lll}
\hline Ana tema & Alt temalar & f \\
\hline & Dikkati artıyor & 9 \\
Etkinliklere Dayalı Bir & Kalıı öğrenme gerçekleşiyor & 7 \\
Öğretimin Öğrencilere & Arkadaşlı ilişkileri gelişiyor & 7 \\
Faydaları & Kendinin ifade edebiliyor & 5
\end{tabular}




\begin{tabular}{ll} 
Özgüveni artıyor & 4 \\
İletişimi kuvvetleniyor & 4 \\
Ürün ortaya koyuyor & 4 \\
Düşünme becerileri gelişiyor & 4 \\
Hafızası güçleniyor & 2 \\
Tasarım ve mekan algısı gelişiyor & 2 \\
Yorum yapabiliyor & 2 \\
Daha mutlu & 2 \\
Önyargları ortadan kalkıyor & 1 \\
\hline
\end{tabular}

Tablo V incelendiğinde etkinliklere dayalı öğretimin öğrencilere faydaları temasının, "dikkati artıyor", "kalıcı öğrenme gerçekleşiyor", "arkadaşlık ilişkileri gelişiyor", "kendilerini ifade edebiliyor", "özgüveni artıyor", "iletişimi kuvvetleniyor", "ürün ortaya koyuyor", "düşünme becerileri gelişiyor", "hafızası güçleniyor", "tasarım ve mekan algısı gelişiyor", "yorum yapabiliyor", "daha mutlu" ve "önyargıları ortadan kalkıyor" şeklinde on üç alt temada toplandığı görülmektedir. Etkinliklere dayalı öğretimin öğrencilere faydaları temasına ilişkin katılımcılardan "KI-1", "Dersten kopmamış oluyorlar. Zaman daha akıcı geçiyor. Dinlemek gerçekten zor bir iş. Dinleme süresini artırıyor."şeklinde görüş belirtmiştir. Katılımcı "KII-4"'ün bu konuya ilişkin görüşü ise şu şekildedir:

“Çocuğun bir şeyler düşünmesi onları yazması grup içinde tartışması çok önemli. Bir şey üretmeye çalışıyor kafa yoruyor. Öğrenci bir çok kazanım elde ediyor. Üretim yapıyor kafa yoruyor. Arkadaşlık ilişkileri gelişiyor. Üst düzey düşünme becerileri gelişmiş oluyor. Kendini ve arkadaşlarını değerlendiriyor. Direk kağıt versek not tuttursak çocuğun düşünme sistemlerini geliştiremeyeceğiz. Eleştirel düşünmesi yaratıcı düşünmesi gelişmiş oluyor." KII-4

Katılımcı görüşlerine göre, öğrencilerin dersi dinleme sürelerinin arttığı, ürün ortaya koyabildikleri, arkadaşlık ilişkilerinin ve üst düzey düşünme becerilerinin geliştiği ifade edilebilir.

Etkinlik hazırlama ve uygulama süreçlerinin daha iyi olması için neler yapılabilir konusunda katılımcılarla yapılan görüşmeler sonucunda, "geliştirilmesi gereken yönlerimiz" teması oluşturulmuştur. Etkinlik uygulamalarında geliştirilmesi gereken yönlerimiz temasının kodları ve frekansları Tablo VI'da sunulmaktadır.

Tablo VI.

Geliştirilmesi Gereken Yönlerimiz Temasına İlişkin Alt Temalar ve Frekanslar

\begin{tabular}{lll}
\hline Ana tema & Alt temalar & f \\
\hline & Süreç değerlendirme & 9 \\
& Sinıfa uyarlama & 8 \\
& Kazanımlara uygun olma & 8 \\
Etkinlik uygulamalarında & Uygulanacağı aşamaya dikkat etme & 8 \\
geliştirilmesi gereken & Uygulama süresine dikkat etme & 8 \\
yönlerimiz & Özgünleşme & 6 \\
& Üst kazanimlara yönelik olma & 5 \\
& Öğrenci gelişimini takip etme & 4 \\
& Etkinliklere dayalı ders işleme & 2 \\
& Soyut konularda etkinlik yapabilme & 2 \\
\hline
\end{tabular}

Tablo VI incelendiğinde etkinlik uygulamalarında geliştirilmesi gereken yönlerimiz temasının, "süreç değerlendirme", "sınıfa uyarlama", "kazanımlara uygun olma", "uygulanacağı aşamaya dikkat etme", "uygulama süresine dikkat etme", "özgünleşme", "üst kazanımlara yönelik olma", "öğrenci gelişimini takip etme", "etkinliklere dayalı ders işleme" ve "soyut konularda etkinlik yapabilme" şeklinde on alt temada toplandığı görülmektedir. Etkinliklere dayalı öğretimde geliştirilmesi gereken yönlerimiz temasına ilgili olarak katılımcilardan "KII-6", "Etkinlik hazırlyyoruz ama özgün etkinlik hazırlamakta zorlanıyoruz" derken "KIII-9", "Bilgi basamağında etkinlik güzel olmuyor. Bilgi basamağının üstündeki kazanımlarla ilgili etkinlikler kullanmamız gerekiyor." şeklinde görüş belirtmektedir. Katılımcı görüşleri incelendiğinde, "KII-6"nın özgün etkinlik hazırlama ve "KıI-9" in bilgi basamağının üstündeki kazanımlara dönük etkinlik hazırlama ile ilgili gelişime ihtiyaçlarının olduğunu belirttikleri görülmektedir.

\section{Uygulama Planının Geliştirilmesi}


Uygulama öncesi toplanan verilerden yola çıkılarak katılımcılara, araştırmacı tarafından etkinliklerin hazırlanması, uygulanması ve değerlendirilmesi aşamalarında nelere dikkat edileceği ile ilgili 12 saatlik bir eğitim verilmiştir. Ayrıca eğitimler sırasında örnek etkinlikler gösterilmiştir. Verilen eğitimin içeriği ve düzenlenme zamanı aşağıda Tablo VII'de gösterilmiştir.

Tablo VII.

Eğitimin İçeriği ve Düzenlenme Tarihleri

\begin{tabular}{lcc}
\hline Eğitimin İçeriği & Tarih & Zaman \\
\hline Etkinlik temelli öğrenme & $28 / 10 / 2017$ & $09: 00-12: 00$ \\
Etkinlik hazırlarken dikkat edilecek hususlar & \\
Etkinlikte materyal kullanımının önemi & \\
Öğrencileri araştırma yapmaya yöneltme ve düşünme becerilerinin kazandırılmasında etkinliklerin & $04 / 10 / 2017$ & $09: 00-12: 00$ \\
önemi & $11 / 11 / 2017$ \\
Bilgi kazanma süreçlerine göre etkinlik hazırlama & $09: 00-12: 00$ \\
Etkinliğin yapılacağı ortamın seçimi & \\
Bireysel ve grup etkinlikleri & $18 / 11 / 2017$ \\
Etkinliklere dayalı ders işleme & $09: 00-12: 00$ \\
Etkinliklerin değerlendirilmesinde kullanılacak ölçme-değerlendirme formları &
\end{tabular}

Verilen eğitimin ardından her zümrenin kendi aralarında işbirliğine giderek birlikte en az iki özgün etkinlik hazırlamaları istenmiştir. Öğretmenler hazırladıkları bu etkinlikleri sınıfta uygularken araştırmacının da gözlem yapması kararlaştırılmıştır. Yapılan her gözlemden sonra etkinliği uygulayan öğretmen ile kısa bir görüşme yapılmış ve gözlemlenen etkinliğin hangi yönlerinin iyi olduğu hangi yönlerinin geliştirilmesi gerektiği araştırmacı tarafından belirtilmiştir.

\section{Uygulama Sürecinde Toplanan Veriler}

Eylem planının uygulanması sürecinde öğretmenlerin yaptıkları etkinlikler, dört hafta boyunca araştırmacı tarafından gözlenmiş ve aksayan yönler hakkında görüşmeler yapılmıştır. Aşağıda Tablo VIII'de etkinliklerin uygulanması sırasında gözlenen davranışlar yer almaktadır.

Tablo VIII.

Etkinliklerin Uygulanması Sürecinde Gözlenen Davranışlar

\begin{tabular}{|c|c|c|c|c|c|c|c|c|c|c|}
\hline Etkinliklerin uygulanması sürecinde gözlenen davranışlar & $\mathrm{K}_{\mathrm{I}-1}$ & $\mathrm{~K}_{\mathrm{I}-2}$ & $\mathrm{~K}_{\mathrm{I}-3}$ & KII-4 & KII-5 & KII-6 & KIII-7 & KIII-8 & KIII-9 & Toplam \\
\hline Etkinlik öğrenci seviyesine ve önbilgilerine uygundu & + & / & + & + & + & + & + & / & + & 8 \\
\hline Etkinlik dersin kazanımları dikkate alınarak hazırlanmıştı & + & + & + & + & + & + & + & + & + & 9 \\
\hline Etkinlik günlük yaşamla ilişkiliydi & + & l & + & + & + & + & + & + & + & 8,5 \\
\hline Öğrencilerin etkinlik için güdülenmeleri sağlandı & - & - & + & / & + & / & - & l & + & 4,5 \\
\hline Öğrencilerin etkin bir şekilde katılımı sağlandı & l & l & + & + & + & + & l & l & + & 7 \\
\hline Etkinlik sürecinde bireysel farklılıklar dikkate alındı & l & l & l & / & l & / & - & l & l & 4 \\
\hline Öğrencilerle iyi bir iletişim kurdu & l & + & + & + & + & + & I & + & + & 8 \\
\hline Öğrencilere her an yardımcı oldu & l & I & + & + & + & + & I & l & + & 7 \\
\hline Görsel ve işitsel araç gereçler kullanıldı & - & / & + & + & + & + & - & + & + & 6,5 \\
\hline Fiziki ortam etkinlik sürecine uygun tasarlanmıştı & + & l & + & l & + & / & + & l & + & 7 \\
\hline Öğrenciler arasında güçlü bir etkileşimin oluşması sağlandı & / & / & + & / & l & / & / & l & + & 5,5 \\
\hline $\begin{array}{l}\text { Etkinlik öğrencilerin katılım, tartışma, doğrulama, eleştirme } \\
\text { gibi gelişim süreçlerine olumlu katkı sundu }\end{array}$ & - & / & + & I & l & / & I & l & + & 5 \\
\hline Öğrencide düşünme süreçlerinin oluşumuna katkı sundu & l & I & l & l & I & / & - & l & I & 4 \\
\hline Ayrılan süre yeterliydi ve zaman verimli kullanıldı & 1 & I & + & I & + & 1 & I & 1 & - & 5 \\
\hline $\begin{array}{l}\text { Etkinlik sürecinde öğrenci davranışları gözlemlendi ve } \\
\text { gerektiğinde not alındı }\end{array}$ & - & - & + & I & I & I & - & - & I & 3 \\
\hline
\end{tabular}

(+): Gözlenmiştir. (-) : Gözlenmemiştir. (/): Kısmen gözlenmiştir.

Tablo VIII incelendiğinde; yapılan etkinliklerin dersin kazanımları dikkate alınarak hazırlanması, günlük yaşamla ilişki kurulması, öğrenci seviyesine ve önbilgilerine uygun olması, öğrencilerle iyi bir iletişim kurulması, öğrencilere yardımcı olunması, fiziki ortamın etkinlik sürecine uygun tasarlanması, görsel ve işitsel araç gereçler kullanılması davranışlarının yüksek düzeyde yerine getirilmeye çalışıldığı ancak; öğrenci davranışlarının etkili bir şekilde gözlenmesi ve gerektiğinde not alınması, bireysel farklılıkların dikkate alınması, öğrencilerin düşünme süreçlerinin oluşumuna katkı sunulması, etkinliğin uygulanabilmesi için 
yeterli sürenin ayrılması ile katılım, tartışma, doğrulama ve eleştirme gibi yönlerden öğrenci gelişimine olumlu katkı sağlayacak davranışların düşük düzeyde yerine getirildiği gözlenmiştir. Gözlem sonrasında katılımcılarla yapılan görüşmelerden bazı anekdotlar aşağıda verilmiştir.

“Hocam dikkat çekme, öğrencilerin güdülenmesi, sınıf yönetimi vb. yönlerden çok güzel bir etkinlik uygulaması yaptınız.
Ancak etkinlik sırasında öğrencilerin bazı üst düzey sorularını gözden kaçırdınız ve etkinlikte süre yetiştirme telaşınız
bunda etkili olmuş olabilir. Eleştirel düşünmeyi sağlayan soruları sorma ve ögrenciden gelen bu tür soruları önemseme
noktasında kendiniz biraz daha geliştirmeniz yapacağınız etkinlikleri daha da nitelikli hale getirecektir.” KI-3
“Dikkat çekme ve etkinliğin nasıl uygulanacağı noktasında öğrencileri yeterince güdüleyemediniz. Bu nedenle de etkinlik
sırasında öğrenciler, size sık sık soru sormak zorunda kaldılar. Bu da sizin ders işleme motivasyonunuzu olumsuz
etkiledi. Bu nedenle süreyi ayarlayamadınız. Öğrenciler konu ile etkinlik arasındaki bağı kurmakta zorlandılar... " KIII-8

Gözlem sonrası yapılan görüşme notları incelendiğine öğretmen“K $\mathrm{K}_{\mathrm{I}-3}$ "'ün etkinlik için yeterli süre ayırma ve öğrenciden gelen üst düzey soruları önemseme; öğretmen "KIII-8"'in öğrenciyi güdüleme ve dikkat çekme boyutlarında kendilerini geliştirmeleri gerektiği anlaşılmaktadır.

Uygulama süreci sonunda katılımcılara "etkinlik çalışmaları değerlendirme ölçeği" tekrar uygulanmıştır. Ölçeğin öntest ve sontest sonuçları Tablo IX'da verilmiştir.

Tablo IX.

Etkinlikleri Değerlendirme Anketi Öntest ve Sontest Sonuçları

\begin{tabular}{ccccccc}
\hline Ölçüm & $\mathbf{N}$ & $\overline{\mathbf{X}}$ & ss & sd & $\mathbf{t}$ & $\mathbf{p}$ \\
\hline Öntest & 9 & 48 &, 77 & 13 & 4,16 & 0,000 \\
Sontest & 9 & 54 &, 52 & & & \\
\hline
\end{tabular}

Tablo IX'da da görüldüğü gibi öğretmenlerin uygulama öncesi etkinlikler çalışmaları değerlendirme ölçeğinin ortalaması $\overline{\mathrm{X}}=48$ iken, uygulama sonrası $\overline{\mathrm{X}}=54$ 'e yükselmiştir $\left(\mathrm{t}_{(19)}=5,66, \mathrm{p}<.05\right)$. Buna göre, yapılan eylem araştırması sonucunda katılımcların etkinlik hazırlama ve uygulama süreçlerinde olumlu yönde bir iyileşmenin olduğu ve bu tür çalışmaların öğretmenlerin niteliğini artırdığı söylenebilir.

\section{Sonuç ve Tartışma}

Sınıf öğretmenlerinin etkinlik hazırlama ve uygulama süreçlerinin değerlendirilmesi amacıyla bu araştırma yapılmıştır. Bu amaca yönelik literatür taramaları yapılmış, eylem araştırması planı geliştirilmiş ve probleme yönelik çözümler üretilmeye çalışılmıştır. Araştırma İstanbul'un Çekmeköy ilçesinde özel bir ilkokulda görev yapan küçük bir öğretmen grubuyla yürütülmüştür. Bu nedenle, araştırmadan çıkan sonuçlar diğer öğretim kademelerinde veya okullarda görev yapan öğretmenlere genellenemeyebileceğinin bilinmesi gerekmektedir. Çünkü farklı yerleşim yerlerinde ikamet eden ve örneklemi daha farklı olan öğretmen gruplarıyla yapılacak çalışmaların sonuçları da farklı olabilir.

Araştırma sürecinin başında toplanan bulgular incelendiğinde katılımcıların yaptıkları etkinliklerin en güçlü beş yönünün; öğrencilerin olumlu davranış kazanması, arkadaşları ile kaynaşması, sosyalleşmesi, başarma duygusunu tatması ve içeriğin günlük yaşamdan kopuk olmaması şeklinde olduğu tespit edilmiştir. Öğretmenlerin yaptıkları etkinliklerin en zayıf beş yönünün ise; öğrencileri araştırma yapmaya yöneltme, bireysel yeteneklerinin ortaya çıkmasına katkı sunma, üst düzey düşünme becerisi kazandırma, temel beceriler ile düşünme becerilerini bütünleştirme, bilgi yükü yerine bilgi kazanma süreçlerine göre etkinlik hazırlama ve bağımsız çalışma alışkanlığı kazanma şeklinde olduğu söylenebilir. Öğretmenlerin etkinlik uygulamalarında geliştirilmesi gereken yönlerinin, ölçme değerlendirme formlarını kullanma, sınıfa ve kazanımlara uygun etkinlik hazırlama, etkinliklerin uygulanacağı aşamaya ve uygulama süresine dikkat etme, özgün etkinlik hazırlama, üst düzey kazanımlar için etkinlik hazırlanma, öğrencinin eğitsel ve öğretimsel gelişimi hakkında bilgi veren etkinlikler hazırlama, etkinliklere dayalı ders işleyebilme ve soyut konularda etkinlik yapabilme şeklinde olduğu belirlenmiştir. Özmantar ve diğerleri (2010), öğretmenlerin etkinlik algılarının kısıtlı olduğunu bu nedenle de gerek etkinliğin tasarımında gerekse uygulanmasında dikkat edilmesi gereken bazı prensipleri yerine getirmekte zorlandıklarını ileri sürmektedirler. Aykaç (2007) da, sınıf öğretmenlerinin etkinlikleri uygulamada kendilerini yetersiz gördüklerini ve etkinlikleri 
uygulamakta zorlandıklarını tespit etmiştir. Açıl (2011) ise, öğretmenlerin etkinlik kavramına ilişkin farklı algılara sahip olduklarını, bu farklı algıların onların uygulama sürecindeki şekillendirmede etkili olduğunu belirtmiştir. Katılımcılar etkinliklerin hem öğretmene ve hem de öğrenciye önemli faydaları olduğunu ifade etmişlerdir. Bu araştırmanın sonuçlarına benzer bir şekilde, öğrencinin öğrenmesinde etkinliklere dayalı öğretimin geleneksel öğretim yaklaşımından daha etkili olduğunu tespit eden araştırmalar bulunmaktadır (Açll, 2011; Batdı, 2014; Camci, 2012; Gözüyeşil, 2012; Jones ve Pepin, 2016; Mishra ve Yadav, 2013; Watson ve Mason, 2007).

Eylem planının uygulanması sonucunda, uygulama öncesine göre, etkinlik hazırlama ve uygulama süreçlerinde olumlu yönde bir iyileşmenin olduğu tespit edilmiştir. Eylem planının uygulanması aşamasında yapılan etkinliklerin; dersin kazanımları dikkate alınarak hazırlanması, günlük yaşamla ilişki kurulması, öğrenci seviyesine ve önbilgilerine uygun olması, öğrencilerle iyi bir iletişim kurulması, öğrencilere yardımcı olunması, fiziki ortamın etkinlik sürecine uygun tasarlanması, görsel ve işitsel araç gereçler kullanılması davranışlarının yüksek düzeyde yerine getirilmeye çalışıldığı ancak; öğrenci davranışlarının gözlenmesi ve gerektiğinde not alınması, bireysel farklılıkların dikkate alınması, öğrencilerin düşünme süreçlerinin oluşumuna katkı sunulması, etkinliğin uygulanabilmesi için yeterli sürenin ayrılması ile katılım, tartışma, doğrulama ve eleştirme gibi yönlerden öğrenci gelişimine olumlu katkı sağlayacak davranışların düşük düzeyde yerine getirildiği gözlenmiştir. Çeşitli araştırmalarda da öğretmenlerin etkinlik uygulamalarında ölçme değerlendirme tekniklerini yeterince kullanmadıkları (Gelbal ve Kelecioğlu, 2007; Öcal, 2012) ve süreyi ayarlamada sorun yaşadıkları tespit edilmiştir (Çubukçu ve Girmen, 2008; Öcal, 2012).

Araştırmanın sonuçlarına bakıldığında, öğretmenlerin etkinlikleri uygularken eleştirel düşünme, yaratıcı düşünme gibi düşünme süreçlerini geliştirecek uygun ortamlar oluşturmak yerine daha çok öğrencinin eğlenmesi ve sıkılmamasına odaklandıkları görülmüştür. Özgen ve Alkan (2014), Öztürk (2016) ve Toprak, Uğurel ve Tuncer (2014), tarafından yapılan araştırmalarda bu araştırmanın sonuçları ile benzerlik göstermektedir. Bu sonuçlara göre öğretmenlere, öğrencide düşüncenin oluşumunu sağlayacak etkinliklerin nasıl yapılacağı ile ilgili eğitimler verilmesi gerektiği söylenebilir. Öğretmenlerin etkinlikleri uygulamalarında ölçme değerlendirme formlarını genellikle kullanmadıkları gözlenmiştir. Öğretmenlerin başta gözlem formları olmak üzere çeşitli ölçme değerlendirme formlarını kullanmaları özendirilmelidir. Ayrıca, etkinlik temelli ders işlemenin öğrencilerin eleştirel düşünme, yaratıcı düşünme gibi düşünme sistemlerine ne gibi etkilerinin olabileceğine dair çeşitli araştırmalar yapılabilir.

\section{Kaynaklar}

Açıl, E. (2011). Illköğretim öğretmenlerinin etkinlik algısı ve uygulanışına ilişkin görüşleri ( Yayınlanmamış yüksek lisans tezi). Gaziantep Üniversitesi, Sosyal Bilimler Enstitüsü, Gaziantep.

Akhalg, M., Chishti, S.H. ve Igbal, M.Z. (2016). Activity based teaching and learning through mentoring in Punjab province of Pakistan: An analysis. Mediterranean Journal of Social Sciences, 7(1), 434-443.

Aykaç, N. (2007). İlköğretim programında yer alan etkinliklerin öğretmen görüşleri doğrultusunda değerlendirilmesi. Ahi Evran Üniversitesi Kırşehir Ĕ̆itim Fakültesi Dergisi, 8(2), 19-35.

Bal, A.P. (2008). Yeni ilköğretim matematik öğretim programının öğretmen görüşleri açısından değerlendirilmesi. Ç.Ü. Sosyal Bilimler Enstitüsü Dergisi, 17(1), 53-68.

Batdı, V. (2014). Etkinlik temelli öğrenme yaklaşımının akademik başarıya etkisi. International Journal of Educational Research, 5(3), 39-55

Bell, A. (1993). Principles for the design of teaching. Educational Studies in Mathematics, 24(1), 5-34.

Bonwell, C.C ve Eison, J.A (1991). Active learning: Creating excitement in the classroom (ASHE-ERIC Higher Education Report No. 1). Washington, DC: George Washington University. http://www.ed.gov/databases/ERIC Digests/ed340272.html adresinden erişildi. 
Büyüköztürk, Ş., Kılıç Çakmak, E., Akgün, Ö. E., Karadeniz, Ş. ve Demirel, F. (2008). Bilimsel araştırma yöntemleri. Ankara: Pegem Akademi.

Camci, F. (2012). Aktif öğrenmeye dayal etkinlik temelli öğretimin öğrencilerin akademik becerilerine ve öğrenme sürecine etkisi (Yayımlanmamış yüksek lisans tezi). Adıyaman Üniversitesi, Adıyaman.

Çubukçu, Z. ve Girmen, P. (2008). Öğretmenlerin sınıf yönetimi becerilerine ilişkin görüşleri. Bilig, 1(44), 123142.

Daymon, C. ve Holloway, I. (2005). Qualitative research methods in public relations and marketing communications. New York: Routledge, Taylor and Francis.

Doyle, W. (1983). Academic work. Review of Educational Research, 53(2), 159-199.

Ferrance, E. (2000). Themes in education: Action research. The Education Alliance: Brown University, Providence, Rhode Island.

Gelbal, S. ve Kelecioğlu, H. (2007). Öğretmenlerin ölçme ve değerlendirme yöntemleri hakkındaki yeterlik algıları ve karşılaştıkları sorunlar. H. Ü. Ĕ̆itim Fakültesi Dergisi, 33, 135-145.

Gözüyeşil, E. (2012). The effect of brain-based learning on academic achievement: A meta analytic study (Yayımlanmamış yüksek lisans tezi). Niğde Universitesi, Niğde.

Guba, E. G. (1981). Criteria for assessing the trustworthiness of naturalistic inquiries. Educational Technology Research and Development, 29(2), 75-91.

Hallinan, M. T. ve Khmelkov, V. T. (2001). Recent developments in teacher education in the United States of America. Journal of Education for Teaching, 27(2), 175-185.

Horoks, J. ve Robert, A. (2007). Task design to highlight task-activity relationships. Journal of Mathematics Teacher Education, 10(4), 279-287.

Johnson, A.P. (2012). A short guide to action research (4. bs.). New Jersey: Pearson Education.

Jones, K. ve Pepin, B. (2016). Research on mathematics teachers as partners in task design. Journal of Mathematics Teacher Education, 19(2), 105-121.

Koç, M.H. (2018). Etkinlik çalışmaları değerlendirme ölçeği: Bir ölçek geliştirme çalışması. International Journal of Social Science, 66(2), 49-59.

Lakshmi, E. ve Hee, S. (2005). Activity-based teaching for effective learning. ITE Teachers' Conference (s. 1-10). Kahului: University of Hawaii.

MacDonald, J. (2008). Blended learning and online tutoring: Planning learner support and activity design (2. bs. ed.). Burlington, USA: Gower Publishing Company

Mills, G. E. (2011). Action research: A guide for the teacher researcher. Upper Saddle River, NJ: Merrill/Prentice Hall.

Mishra, S.K. ve Yadav, B. (2013). Effect of activity-based approach on achievement in science of students at elementary stage. International Journal of Basic and Applied Science, 1(4), 716-733.

Norton, L.S. (2009). Action Research in Teaching and Learning: A Practical Guide to Conducting Pedagogical Research in Universities. Routledge: London.

Öcal, H.A. (2012). Etkinlik temelli öğretimin uygulanmasına ilişkin öğretmen görüşleri (Yayınlanmamış yüksek lisans tezi). Gaziantep Üniversitesi, Sosyal Bilimler Enstitüsü, Gaziantep.

Özgen, K. ve Alkan, H. (2011). Matematik öğretmen adaylarının öğrenme stillerine göre etkinliklere yönelik tercih ve görüşlerinin incelenmesi. Hacettepe Üniversitesi Eğitim Fakültesi Dergisi, 41, 325-338.

Özmantar, M. F. ve Bingölbali, E. (2009). Etkinlik tasarımı ve temel tasarım prensipleri. E. Bingölbali ve M. F. 
Özmantar (Ed.), İlköğretimde karşılaşılan matematiksel zorluklar ve çözüm önerileri (s. 313-348). Ankara: Pegem Akademi.

Özmantar, M. F., Bozkurt, A., Demir, S., Bingölbali, E. ve Açıl, E. (2010). Sınıf öğretmenlerinin etkinlik kavramına ilişkin algıları. Selçuk Üniversitesi Ahmet Keleşoğlu Eğitim Fakültesi Dergisi, 30, 379-398.

Öztürk, F. (2016). Illköğretim matematik öğretmenliği adaylarının etkinlik hazırlama ve uygulama süreçlerinin hazırlanması (Yayınlanmış yüksek lisans tezi). Atatürk Üniversitesi, Erzurum.

Schmuck, R. A. (1997). Practical action research for change. Arlington Heights, IL: Skylight Professional Development.

Selley, N. (1999). The art of constructivist teaching in the primary school. London: David Fulton Publishers.

Sullivan, P., Clarke, D. ve Clarke, B. (2013). Teaching with tasks for effective mathematics learning. New York: Springer Science+Business Media.

Süleymangil, M.(2013). Sınıf içi öğretim etkinliği geliştirme ve kullanma çalışmalarının sını öğretmenlerinin mesleki gelişimleri üzerindeki rolü (Yayınlanmamış yüksek lisans tezi). Adnan Menderes Üniversitesi, Sosyal Bilimler Enstitüsü, Aydın.

Swan, M. (2007). The impact of the task- based Professional development on teachers' practices and beliefs: A design research study. Journal of Mathematics Teacher Education, 10(4), 217-237.

Şahan, H. (2000). Sosyal bilgiler dersinin bilimsel davranışları kazandırma yönünden öğretmen görüşlerine göre değerlendirilmesi (Yayınlanmamış Yüksek Lisans Tezi). Balıkesir Üniversitesi, Sosyal Bilimler Enstitüsü, Balıkesir.

Toprak, Ç., Uğurel, I. ve Tuncer, G. (2014). Öğretmen adaylarının geliştirdikleri matematik öğrenme etkinliklerinin seçilen konu, amaç, uygulama şekli bileşenleri açısından analizi. Turkish Journal of Computer and Mathematics Education, 5(1), 39-59.

Yıldırım, A. ve Şimşek, H. (2016). Sosyal bilimlerde nitel araştırma yöntemleri. Ankara: Seçkin Yayıncılık.

Watson, A. (2008). Task transformation is the teacher's responsibility. Proceedings of the 32nd Annual Meeting of the North American Chapter of the International Group for the Psychology of Mathematics Education, Morelia: Michoacán, Mexico.

Watson, A. ve Mason, J. (2007). Taken-as-shared: A review of common assumptions about mathematical task in teacher education. Journal of Mathematics Teacher Education, 10(4), 205-215. 


\section{EXTENDED ABSTRACT}

\section{Introduction}

Activity based learning is based on the students' conducting meaningful learning activities and thinking on what they are doing. Activity based teaching is method which teaches students how to think individually in the face of their own problems, facilitating the discovery of practical solutions and providing the necessary self-confidence for learning. In this study, the purpose has been to conduct an activity research aimed at evaluating the activity preparation and implementation processes of classroom teachers. In this respect, the perception of the classroom teachers who work in a private school concerning activity and the aspects they need to develop in the activity preparation and implementation process have been revealed. In the literature, the absence of a study in which the activity preparation and implementation processes of classroom teachers working in private schools are studied in our country makes this study important.

\section{Method}

The study was designed as an action research, quantitative and qualitative data collection techniques were used. In the study, the Mills Model as one of the action research models was used. The working group of the research consists of nine primary school teachers of a private school in the administrative district of Çekmeköy of the province of Istanbul in the 2017-2018 fall semesters. The working group consists especially of classroom teachers working in the $1^{\text {st }}, 2^{\text {nd }}$ and $3^{\text {rd }}$ Grades of the subject primary school. In the study, one of the random sampling methods, purposeful sampling method was used. In order to be used in the collection of quantitative data, an "Activity Works Evaluation Survey" consisting of 20 items was developed by the researcher. Semistructured interview forms were used by the researcher and face to face interviews were made with all participants. There are four questions in the interview form. The researcher has preferred to collect data by conducting semi-structured observations during the implementation phase of the action plan. Data collected during the research though interviews and observation were subject to "content analysis" technique as one of the data analysis varieties. On the other hand, SPSS statistics 21 program was used during the quantitative analysis. In the evaluation of the data, the aim has been to determine the opinions of the participants on the activity studies by calculating arithmetic average and standard deviations. Furthermore, pretest and posttest results were tested with paired samples t-test.

\section{Results}

When the findings collected at the beginning of the research process are studied, the three strongest aspects of the activities carried out by the participants were found to consist of enabling students to acquire positive behaviors, being suitable for the student's level, contributing to psychomotor development, ensuring that students get on well together and are motivated in the lessons. The five weakest aspects of the activities carried by the teachers can be mentioned as guiding children to research, contributing to bring out their individual talents, building their skills for critical thinking, integrating their thinking skills with basic skills and preparing activities according to information acquisition processes instead of information load. The aspects of the teachers need to be develop in the implementation of activities are using assessment and evaluation forms, preparing activities suitable for the class and the learning outcomes, paying attention to the phase in which activities shall be implemented and the duration of implementation, preparing original activities, preparing activities for top learning outcomes, preparing activities that provide information on the student's educational and instructional development, ability to teach lessons based on activities and to perform activities in abstract matters.

As a result of the implementation of the action plan, in comparison to what it had been prior to the application, a positive development was detected in the activity preparation and implementation processes. In the activities performed during the implementation phase of the action plan, it was observed that teachers displayed a high level of performance in preparing the course by taking to account the learning outcomes of the lesson, establishing a connection to daily life, its being adequate for the student's level and foreknowledge, using audiovisual tools, establishing a good communication with the students designing the physical 
environment in line with the activity process and helping children whereas concerning certain behaviors that would contribute positively to the student development such as observing the student's behavior and taking notes when necessary, allocating sufficient time to the implementation of the activity, taking to account individual differences, creating students' thinking processes, the teachers' performance was observed to be low.

\section{Conclusion}

When the results of the study are examined, it was observed that teachers would, instead of creating adequate environments for the development of thinking processes such as critical thinking, creative thinking, rather focus on the student's having a good time and not being bored. It is possible to say that teachers should be given trainings on how to conduct activities that would create thinking in the student. It was observed that the teachers would not use in general the assessment and evaluation forms in the implementation of activities. Teachers should be encouraged to use various assessment and evaluation forms led by observation forms. Conducting various studies concerning which effects activity-based lesson teaching may have on critical thinking and creative thinking systems of students is advisable. 